\title{
Current multiple sclerosis treatments have improved our understanding of MS autoimmune pathogenesis
}

\author{
Martin, Roland ; Sospedra, Mireia ; Rosito, Maria ; Engelhardt, Britta
}

DOI: https://doi.org/10.1002/eji.201646485

Posted at the Zurich Open Repository and Archive, University of Zurich ZORA URL: https://doi.org/10.5167/uzh-126722

Journal Article

Accepted Version

Originally published at:

Martin, Roland; Sospedra, Mireia; Rosito, Maria; Engelhardt, Britta (2016). Current multiple sclerosis treatments have improved our understanding of MS autoimmune pathogenesis. European Journal of Immunology, 46(9):2078-2090.

DOI: https://doi.org/10.1002/eji.201646485 


\title{
Current multiple sclerosis treatments have improved our understanding of MS autoimmune pathogenesis
}

Roland Martin ${ }^{1}$, Mireia Sospedra ${ }^{1}$, Maria Rosito $^{2}$ and Britta Engelhardt ${ }^{2}$

${ }^{1}$ Neuroimmunology and Multiple Sclerosis Research Section, Department of Neurology University Hospital

Zurich, Zurich, Switzerland

${ }^{2}$ Theodor Kocher Institute, University of Bern, Bern, Switzerland

\section{Correspondence:}

Roland Martin

Department of Neurology University Hospital

Zurich, Switzerland

E-mail: Roland.Martin@usz.ch

Britta Engelhardt

Theodor Kocher Institute

University of Bern, Switzerland

E-mail: bengel@tki.unibe.ch

Keywords: multiple sclerosis, treatment, autoimmunity, experimental autoimmune encephalomyelitis, autoimmune pathogenesis, autoreactive T cells, autoreactive B cells, autoantibodies

\begin{abstract}
Abbreviations:
aHSCT, autologous hematopoietic stem cells transplantation; APC, antigen presenting cell; BBB, Blood Brain Barrier; BDNF, brain-derived neurotrophic factor; Campath-1, chimeric anti-CD52 monoclonal antibody; CIS, clinically isolated syndrome; CNS, central nervous system; CSF, cerebrospinal fluid; DMF, Dimethylfumarate; Daclizumab-HYP, daclizumab high yield process; DNAM-1, DNAX accessory molecule-1; EAE, experimental autoimmune encephalomyelitis; FTY720, Fingolimod; GA, Glatiramer Acetate; GM-CSF, Granulocyte macrophage-colony stimulating factor; GWAS, genome-wide association studies; HSV1, herpes simplex virus 1; IFN $\beta$, Interferon $\beta$; IFN- $\boldsymbol{\gamma}$, Interferon $\gamma$; JCV, JC polyoma virus; LTi, Lymphoid tissue inducer; MBP, myelin basic protein; MOG, myelin oligodendrocyte glycoprotein; MS, Multiple sclerosis; Nrf2, nuclear factor related factor 2; NTZ, Natalizumab; NK, natural killer; MAIT, mucosal-associated invariant T; MФ-macrophage; MRI, magnetic resonance imaging; PC, plasma cell; PLP, proteolipid protein; PML, progressive multifocal leukoencephalopathy; PPMS, primary progressive MS; RRMS, Relapsing-remitting MS; SNPs, single nucleotide polymorphisms; SPMS, secondary progressive MS; S1PR, sphingosin-1 phosphate receptors; TCRs, T cell receptors; TCM, central memory T cells; $\mathrm{T}_{\mathrm{EM}}$, effector memory T cells, $\mathrm{T}_{\mathrm{EMRA}}$, effector memory recently activated T cells; Th1, T helper 1; TNF- $\alpha$, tumor necrosis factor $\alpha$; TNFR, tumor necrosis factor receptor; VCAM-1, vascular cell adhesion molecule 1 ; VLA-4, very late antigen-4; VZV, varicella zoster virus.
\end{abstract}




\begin{abstract}
Multiple sclerosis (MS) is the most common inflammatory disorder of the central nervous system (CNS) in young adults. When MS is not treated, it leads to irreversible and severe disability. The etiology of MS and its pathogenesis are not fully understood. The recent discovery that MS-associated genetic variants code for molecules related to the function of specific immune cell subsets is consistent with the concept of MS as a prototypic, T cell-mediated autoimmune disease targeting the CNS. While the therapeutic efficacy of the currently available immunomodulatory therapies further strengthen this concept, differences observed in responses to MS treatment as well as additional clinical and imaging observations have also shown that the autoimmune pathogenesis underlying MS is much more complex than previously thought. There is therefore an unmet need for continued detailed phenotypic and functional analysis of disease-relevant adaptive immune cells and tissues directly derived from MS patients to unravel the immune etiology of MS in its entire complexity. In this review, we will discuss the currently available MS treatment options and approved drugs, including how they have contributed to the understanding of the immune pathology of this autoimmune disease.
\end{abstract}




\section{Introduction - Multiple sclerosis as an autoimmune disease}

MS is considered a prototypic organ-specific autoimmune disease targeting the CNS with inflammatory lesions, demyelination, axonal/neuronal damage and metabolic changes [1, 2]. Relapsing-remitting and secondary progressive MS (RRMS, SPMS) are the two most frequent forms of MS, which often affect young adults between 20 and 40 years of age, and women 3 times more often than men [3]. Typical clinical signs include temporary loss of vision, sensory and motor problems, but also fatigue, neurocognitive changes, and impairment of bladder-, bowel- and sexual functions. During the relapsing-remitting phase neurological deficits, which occur in bouts and may last from days to a few weeks, usually disappear again, but after several years, disability gradually builds up. Depending on the individual course this secondary progressive disease with continuously increasing disability may never set in, but often starts after 15-20 years of RRMS. In a small percentage of patients such a progressive course is seen from the beginning, which is referred to as primary progressive MS (PPMS) and seen in females and males with equal frequency [3].

Evidence for an autoimmune pathogenesis of MS was shown in its animal model, experimental autoimmune encephalomyelitis (EAE) (summarized in [4, 5]). Studies in EAE models in mouse, rat, guinea pig and monkey have led to a better understanding of some aspects of MS biology and have in some instances helped to develop the current MS therapies, two of which target immune cell trafficking (see below). EAE is induced by subcutaneous immunization of susceptible naive recipients with CNS myelin antigens in complete Freund's adjuvant or by the adoptive transfer of freshly activated neuroantigen/myelin-specific CD4 ${ }^{+}$T helper 1 (Th1) or Th17 cell blasts (summarized in $[5,6]$ ). Thus, autoreactive $C D 4^{+} T$ cells are sufficient to induce an inflammatory demyelinating disease that is similar to MS. Nevertheless, several treatments that were successful in EAE failed in MS trials, underlining the fact that MS pathogenesis is more complex than that mimicked by the current EAE models (summarized in [7]).

Research of the immune system in MS patients has established that MS is an autoimmune disease with T cells, B cells, and probably also autoantibodies as the most important factors contributing to its immunopathogenesis $[1,8,9]$. Autoreactive $\mathrm{CD}^{+}$T cells with Th1 (secreting IFN- $\gamma$ ) or Th1* (secreting IFN- $\gamma$ and IL-17), or those secreting IFN- $\gamma$ and GM-CSF $[1,10,11]$, play an important role in MS, which is partly supported by data from the EAE models [6]. In addition, high avidity myelin-specific $\mathrm{CD}^{+} \mathrm{T}$ cells are directed against immunodominant peptides of myelin basic protein (MBP), proteolipid protein (PLP) and myelin oligodendrocyte glycoprotein (MOG), and several peptide epitopes are similar or identical to those that are most often used to induce EAE [1]. However, it is likely that additional target antigens will be discovered in the future. CD4 ${ }^{+}$Th2 cells (secreting IL-4, L-5 and IL-13) have recently been described in pattern II MS [12], an antibody-mediated subform of MS [13]. The transgenic expression of MBP-specific T cell receptors (TCRs) and the MS-associated HLA-class II molecules in mice [14-16], but particularly also findings along the treatments of 
MS ([17]; see in detail below) have highlighted the importance of CD4 ${ }^{+}$T cells as central pathogenic factor in MS. Further evidence is the strong association of MS with the DR15 haplotype. This HLA-class association was described in 1972 as the first for any autoimmune disease [18], and it is now firmly established as the most important genetic risk factor of MS [19]. Beyond the DR15 haplotype and the observation of HLA-A2 as a protective and HLA-A3 as risk-increasing HLA-class I allele, genetic research has been very successful during the last ten years. Several large genome-wide association studies (GWAS) have identified more than 150 common genetic variants (single nucleotide polymorphisms; SNPs) [19, 20]. Interestingly, the vast majority of these genetic variants include cytokines and cytokine receptors, transcription factors, adhesion and costimulatory molecules linked to the immune system $[19,20]$. However, autoreactive CD4 ${ }^{+} \mathrm{T}$ cells are not the only "player" in MS. $C D 8^{+}$T cells are found more abundantly than $\mathrm{CD}^{+}$cells in MS brain lesions [21], and recently a few $\mathrm{CD} 8^{+}$ cell-mediated EAE models have been developed [22]. Since the target cells of the autoimmune process in MS, oligodendrocytes and neurons, do not express HLA-class II, but HLA-class I molecules, CD8 ${ }^{+}$T cells are more likely to be the main effectors that lead to tissue damage [23, 24]. Moreover, a role for myelin-specific autoantibodies has long been suspected, and more than $30 \%$ of MS patients show serum and/or CSF antibodies that are able to damage myelin and/or axons [25]. Among the potential target antigens of autoantibodies in MS MOG [26], neurofascin [27], contactin-2 [28], the potassium channel, KIR-4.1 [29], are the most studied; however, further research is needed. Experience with B cell-depleting antibodies indicates that the antigenpresenting function of B cells may be as, or even more, important as autoantibody formation in driving MS [30, 31]. Innate immune cells such as macrophages, dendritic cells (DCs), microglia and natural killer (NK) cells are involved in MS development at various stages of the immune activation as effector or regulatory cells, and during the chronic compartmentalized inflammation in the brain, which characterizes the chronic progressive stage of MS [32].

\section{Treatments of MS}

As already noted above, the various treatments of MS deserve particular mentioning not only because they have changed clinical practice and can be considered a continuing "success story" in the field of neurological diseases, but also because they have taught us important lessons about the immune mechanisms of MS. The fact that immunomodulatory treatments reduce relapse rates in MS by up to $60 \%$ and have even more profound effects, when magnetic resonance imaging (MRI) is used to measure disease activity [30, 33-35], underscores that MS is an immune-mediated disease. Until the late 1980s no treatment for MS was available other than giving steroids during acute MS exacerbations. While relapse treatment has not changed, there are now 10 drugs that have been approved for the various forms of MS from the first clinical manifestation (clinically isolated syndrome, CIS) over RRMS to SPMS [36], and, for the first time also for PPMS. Each one of the currently available treatments, and a few additional ones that have not been approved, are briefly outlined below and highlight the lessons that we have learnt from them (Table 1 and Figure 1). 


\section{Interferon-beta (IFN- $\beta$ )}

Five different versions and subcutaneous application forms of IFN- $\beta$ have been approved between 1993 and 2015 for CIS, RRMS and SPMS. IFN- $\beta$ was originally tested in MS patients as intrathecal injections with the hypothesis that viral infections cause or sustain MS [37]. It had not been explored in the EAE model prior to testing in MS patients. IFN- $\beta$ reduces relapse rates by approximately $30 \%$ and is very well tolerated [38] (see Table 1 and Fig. 1). Since its first use, several hundred studies have examined the mechanisms of IFN- $\beta$ treatment in MS. The most important mechanisms of action for IFN- $\beta$ which have been shown include: stabilization of the blood-brain barrier (BBB) by blocking matrix metalloproteases in in vitro models and in treated MS patients [39-41], the downregulation of HLA-class II molecules and antigen presentation on glial cells and B cells in vitro [42], and the inhibition of proinflammatory and upregulation of Th2 cytokines by T cells of IFN- $\beta$-treated patients [43,44], although some of these observations remain controversial [45]. Whether IFN- $\beta$ antiviral activity also contributes to the clinical effects is not clear, but more than 20 years of clinical use have shown that IFN- $\beta$ treatment does not lead to any compromise of the immune system with respect to protection against viral, bacterial or fungal infections.

\section{Glatiramer-acetate (GA)}

Sela and colleagues developed random copolymers with a specific amino acid composition in order to mimic myelin proteins and to induce EAE [46]. Surprisingly, glatiramer-acetate (GA), which is composed of polypeptides with the amino acids glutamate, lysine, alanine and tyrosine in random order and a fixed molar ratio of 1.9 to 4.7 to 6.0 to 1.0 , did not induce but rather improve EAE [46]. After a tortuous clinical development, GA was first approved in 1996. GA needs to be injected subcutaneously, inhibits relapse rates by approximately $30 \%$, and is very well tolerated [47]. Several studies have investigated the immunomodulatory effects of GA. Among them, GA interferes with antigen presentation in the EAE model and human myelinspecific T cell clones [48], shifts the proinflammatory T-cell response in MS to one that is immunomodulatory and Th2-like in the EAE model [49] and also in T cells of GA-treated patients [50], induces regulatory CD8 ${ }^{+} \mathrm{T}$ cells in GA-treated patients [51], shifts the phenotype of monocytes from a proinflammatory (M1) to a regulatory (M2) type in EAE [52], and induces the production of neurotrophic factors such as brain-derived neurotrophic factor (BDNF)[53-55] [47] (see Table 1 and Fig. 1). Which of these GA immunomodulatory effects are most important in reducing the disease activity in MS is difficult to assess, but its activity profile is unique and it also does not compromise protective immune responses.

\section{Anti- $\alpha 4$-integrin (natalizumab)}

Seminal findings by Yednock et al. demonstrated in 1992 that blocking very late antigen-4 (VLA-4; $\alpha 4 \beta 1$ integrin)-mediated adhesion of immune cells profoundly inhibits EAE activity [56]. Prior to the in vivo EAE experiments they tested several monoclonal antibodies for their ability to inhibit adhesion of cells derived from 
a monocytic cell line to cerebral vessels in inflamed EAE brain tissue and showed that attachment of activated lymphocytes and monocytes is inhibited by antibodies against $\alpha 4 \beta 1$ integrin [56] (see Table 1 and Fig. 1).

Subsequent studies from other groups confirmed these findings and identified VCAM-1 as the vascular ligand for VLA-4 [57]. A humanized $\alpha 4$-integrin blocking IgG4 antibody (natalizumab) was subsequently developed for the treatment of RRMS and shown to be efficacious in blocking relapse rates to a much higher extent than IFN$\beta$ and GA [33]. Natalizumab is very well tolerated except for one adverse event, JC polyoma virus (JCV)associated progressive multifocal leukoencephalopathy (PML), an opportunistic and often fatal infection of the brain. Approximately 600 cases of PML have been reported in natalizumab-treated MS patients until now, and more than $20 \%$ of patients have died [58]. PML occurs in situations of hereditary or acquired immunocompromise [59]. Natalizumab efficiently prevents activated CD4 ${ }^{+}$T cells from entering the CNS, and it is currently believed that this mechanism, which is desired in MS, compromises physiological immune surveillance of the brain [60]. Furthermore, inhibition of VLA-4/VCAM-1 interactions by natalizumab also induces the release of hematopoietic precursor cells and marginal zone B cells from their physiological niches in bone marrow and lymphoid organs into the peripheral blood [61]. To which extent the latter mechanisms contribute to PML remains to be shown. Risk stratification with anti-JCV antibody titers has helped in determining, in which patients the treatment is relatively safe, but, despite the high efficacy and overall very good tolerability, the risk of PML is a serious problem when treating MS patients with natalizumab. Ongoing research tries to identify why natalizumab, which targets a very specific cell-cell interaction, contributes to such a rare viral infection [62].

The sphingosin 1-phosphate receptor agonist fingolimod

Fingolimod, a derivative of the fungal antibiotic myriocin, is a functional antagonist of four of the five sphingosin-1 phosphate receptors (S1PR), which are expressed by many cells including immune cells [63, 64]. Fingolimod was first tested in transplant models, before it was developed for MS [65]. Early studies in the EAE model demonstrated that EAE is ameliorated and that fingolimod inhibits the recirculation of T cells to the CNS [66]. After successful clinical development [67], fingolimod was approved as the first oral drug in MS in 2011. It is more effective with respect to reducing relapse rates in RRMS than IFN- $\beta$ and GA, but less than natalizumab [67]. Fingolimod acts by a different mechanism of action than all previously mentioned compounds. Fingolimod binds to S1PRs and leads to their internalization and degradation. Since the S1P-mediated signal is necessary for egress of CCR7-expressing lymphocytes from lymph nodes [68], fingolimod leads to trapping of naive and central memory cells in lymph nodes, while CCR $7^{\text {neg }} \mathrm{T}$ effector memory and effector memory recently activated T cells (TemRA) are not affected [63] (see Table 1 and Fig. 1). The result is a relative lymphopenia and change in composition of peripheral lymphocytes. This effect of fingolimod is considered the main mechanism of action in MS; however, multiple other activities on immune cells and CNS including the BBB have been demonstrated. Interestingly, fingolimod also leads to a subtle defect in immunocompetence regarding control of viral infection [69]. Only two herpes viruses that reside in cells of the nervous system, i.e. varizella zoster virus (VZV) and herpes simplex virus 1 (HSV1), are affected by fingolimod treatment [69, 70]. More frequent reactivation of 
these two viruses from the latent state and, in a few cases, severe generalized VZV infection and HSV1 encephalitis even with fatal outcome have occurred [70]. PML has been observed as well under fingolimod treatment, but only in very few cases compared with natalizumab [71].

\section{Teriflunomide}

Teriflunomide is a metabolite of leflunomide $[72,73]$. Teriflunomide was approved in 2012 as oral drug for treating RRMS. Teriflunomide reduces the relapse rates similar to IFN- $\beta$ and GA treatments [74], but is not as active as fingolimod and dimethylfumarate (DMF) $[67,75]$. The main mechanism of action is the inhibition of dihydro-orotate-synthetase, a key enzyme in the synthesis pathway of pyrimidine nucleotides [76] (see Table 1 and Fig. 1). As a result teriflunomide inhibits the proliferation of activated T lymphocytes. No immunocompromise with respect to certain viral or bacterial infections has been observed so far.

\section{Dimethylfumarate}

Dimethylfumarate (DMF) and other derivatives of fumaric acid ester compounds have been used for more than four decades to treat psoriasis [77] before the efficacy of this compound was also shown in MS [75]. DMF was approved as oral treatment for MS in 2013. The efficacy of DMF regarding reduction of relapse rate is probably comparable to fingolimod [75]. Fumaric acid esters, including DMF, have been shown to alter the activation state of DCs and shift the proinflammatory immune reaction to a Th2-like one [78] (see Table 1 and Fig. 1). Further activities include cytoprotective effects via induction of the transcription factor nuclear factor related factor 2 (Nrf2) [79] and the induction of regulatory B-cell subsets [80]. It can be anticipated that additional mechanisms of action will be identified based on the clinical observation of sometimes profound and longlasting lymphopenia in some patients. So far, no specific immunocompromise with respect to viral or bacterial infections has been reported, but a few PML cases have been observed [81].

\section{Anti-CD52 (alemtuzumab)}

A chimeric anti-CD52 monoclonal antibody (Campath-1) has been one of the first monoclonals used to treat human diseases, i.e. for hematopoietic malignancies such as non-Hodgkin lymphoma and chronic lymphatic leukemia, as well as for graft-versus-host disease [82, 83]. Campath-1 leads to prolonged depletion of CD52expressing lymphocytes, which includes a wide variety of T and B lymphocytes (see Table 1 and Fig. 1). Interestingly, the physiological role of CD52 is still not known. Compston, Coles and colleagues showed that Campath-1 efficiently blocks the inflammatory activity (relapses and new contrast-enhancing MRI lesions) in RRMS, among other effects by the lymphocyte depletion and relative dominance of CD4+CD25high regulatory T cells during reconstitution [84]. Based on these results, a humanized version of Campath-1, named alemtuzumab, was successfully tested in RRMS [34] and approved in 2014. Alemtuzumab significantly reduces 
clinical and MRI disease activity [34]. Particularly, $\mathrm{CD}^{+}{ }^{+}$cells are depleted for long periods of time, and alemtuzumab is usually given only twice as short treatment courses in yearly intervals [85]. However, some patients require additional treatment courses, and surprisingly, approximately $30 \%$ of alemtuzumab-treated MS patients develop secondary autoimmune diseases, i.e. autoimmune thyroid disease, immune throbocytopenia or Goodpasture syndrome [86].

\section{Anti-CD20 (rituximab, ocrelizumab, ofatumumab)}

B-cell depleting therapies with anti-CD20 antibodies have provided evidence for an involvement of B cells in MS pathogenesis. Targeting B cells with the depleting antibody rituximab, a chimeric anti-CD20 monoclonal antibody, was first approached with the idea that B cells and their autoantibodies contribute to MS pathogenesis [30]. Rituximab had been developed and approved for treating B-cell malignancies and rheumatoid arthritis. CD20 is expressed on all B-cell differentiation stages except the very early and very late (plasma cells) ones. Rituximab depletes CD20-expressing B cells primarily via complement-mediated lysis and very effectively reduced inflammatory activity in RRMS, as shown by less contrast-enhancing MRI lesions [30] (see Table 1 and Fig. 1). Interestingly, this effect was observed already after 8 weeks of treatment, much earlier than would be expected, if a reduction of autoantibodies were the main effect. Humanized (ocrelizumab) and human (ofatumumab) anti-CD20 monoclonals have now been developed and shown high efficacy in RRMS in phase III (ocrelizumab) [87] and phase II studies [88] (summarized in [36]). Further, a subgroup analysis in the study by Hawker et al. [89] indicated that rituximab attenuates disease progression in primary progressive MS (PPMS) in patients younger than 51 years and with signs of disease activity by MRI. Recently, efficacy in PPMS has been shown formally for ocrelizumab [90]. Recent data on proinflammatory GM-CSF-secreting B cells support this notion [31]. In addition, leptomeningeal lymphoid follicular B-cell infiltrates associated with EBV activation have been observed in brain tissues from MS patients [91]. The frequent adjacent localization of cortical lesions suggests that factors produced in these leptomeningeal follicles reach the CNS parenchyma and damage myelin and neuronal cells in the vicinity [91]. These findings could provide an explanation for the observation of oligoclonal Ig production in the CSF and the frequent occurrence of grey matter lesions in MS patients [92].

\section{Anti-CD25 (daclizumab)}

Daclizumab is a humanized monoclonal antibody against CD25, the alpha chain of the IL-2 receptor. It was originally approved for the prevention of allotransplant rejection with the concept that it would block the expansion of alloreactive T cells [93]. CD25 is found in the heterotrimeric high affinity IL-2 receptor complex composed of alpha- (CD25), beta- (CD127) and common gamma (CD132) chain [94]. Following promising observations in treatment-resistant uveitis [95], daclizumab was also used in IFN-non-responding RRMS patients and showed high efficacy regarding reduction of inflammatory MRI lesions [96]. Mechanistic studies along this trial documented that the effects of anti-CD25 treatment on T cells, including Treg cells, are only 
modest, but a marked expansion of CD56 bright NK cells was observed [97] (see Table 1 and Fig. 1). The expansion of $\mathrm{CD} 56^{\text {bright }} \mathrm{NK}$ cells correlates strongly with the reduction of inflammatory lesions in the brain in multiple phase II and phase III studies. Interestingly, CD56 ${ }^{\text {bright }}$ NK cells do not exist in mice, and the expansion of an immune cell population with immunomodulatory, anti-viral and anti-tumor effects is a unique mechanism-ofaction compared with the above depleting antibodies [97]. Several other interesting mechanisms of action have been described for daclizumab, including inhibition of IL-2 transpresentation by DCs [98], and inhibition of LTi cell development [99]. Furthermore, a recent study not only corroborates prior data that CD56 ${ }^{\text {bright }}$ cells expand during daclizumab treatment and are capable to lyze activated $\mathrm{CD}^{+} \mathrm{T}$ cells directly [97], but adds to the mechanistic understanding by showing that daclizumab treatment corrects impaired interactions between DNAX accessory molecule (DNAM)-1 on NK cells and its ligand CD151 on CD4 ${ }^{+}$T cells [100]. A new formulation of daclizumab (daclizumab-HYP) has recently shown good clinical efficacy [35], and daclizumab-HYP was just approved by the Food and Drug Administration in May 2016.

\section{Autologous hematopoietic stem cell transplantation (aHSCT)}

Autologous hematopoietic stem cell transplantation (aHSCT) is used to reconstitute the immune system with autologous $\mathrm{CD}_{3} 4^{+}$hematopoietic precursor cells after, for example, myeloablative chemotherapy for various cancers. i.e. breast cancer [101]. aHSCT has also been explored as a treatment option in severe autoimmune diseases including MS for over 20 years now [102]. The idea is that a dysfunctional adaptive immune system can be eliminated by lympho- or myeloablative conditioning regimen (chemotherapy, previously whole body irradiation) and then be re-established with autologous $\mathrm{CD}_{3} 4^{+}$stem cells that had been collected from the patient prior to the chemotherapy. Initially, aHSCT was only used in advanced and highly active MS cases due to a mortality risk of $7 \%$ prior to 2000 [102]. Since 2000 , the mortality has dropped to $1.2 \%$, and now it will probably be even lower. Although no pivotal phase III trial has been performed yet, controlled phase II studies [103] and many case series indicate that aHSCT is highly efficacious in completely blocking MS disease activity for long periods of time and in the majority of patients [102, 104, 105]. Mechanistic studies showed that the concept of immune reconstitution by aHSCT is indeed correct in that the T-cell repertoire is completely renewed [106](see Table 1 and Fig. 1), and conventional and mucosal-associated invariant T (MAIT) cells are completely depleted [107], again strongly supporting the autoimmune pathogenesis of MS.

\section{Further MS treatment-related observations}

The study of other cytokines or inhibitors thereof aside from IFN- $\beta$ as possible therapeutic targets, e.g. TNF- $\alpha$ inhibitors and the administration of IFN- $\gamma$, originally yielded promising results in EAE [108], but then not only failed in clinical translation, but also were associated with MS worsening. Increased levels of TNF- $\alpha$ in serum and CSF of MS patients correlate with disease severity, indicating a role for TNF- $\alpha$ in MS pathogenesis [109]. However, blocking TNF- $\alpha$ with lenercept, a recombinant soluble tumor necrosis factor receptor 1 (TNFR1) fusion protein, induced exacerbations of MS when compared with placebo controls [110]. In addition, onset of MS or demyelinating disease similar to MS has been reported in rheumatoid arthritis patients treated with a soluble TNFR2 fusion protein (etanercept) or with anti-TNF- $\alpha$ antibodies (infliximab) [111]. Interestingly, EAE 
studies performed after the clinical trial have highlighted the pleiotropic effects of TNF- $\alpha$ and its two receptors, TNFR1 and TNFR2, in MS pathogenesis, and indicated that TNF- $\alpha$ signaling via TNFR2 on brain cells might be critical for repair processes in the CNS, beyond its proinflammatory effect (summarized in [112]). Similarly, the observations of a protective role of IFN- $\gamma$ in EAE pathogenesis (summarized in [112]) failed to translate to MS, since the administration of IFN- $\gamma$ was shown to aggravate the disease in MS patients [113]. Follow-up studies in the EAE model have demonstrated that IFN- $\gamma$ is involved in the pro-inflammatory responses e.g. augmenting MHC class I and II expression on glial cells, and interferes with repair processes in the brain [114].

Further, IL-12 and IL-23 have been shown to have essential roles in the differentiation of pathogenic Th1 and Th17 cells inducing EAE [115]. Nevertheless, when Ustekinumab, an anti-human IL-12/IL-23p40 antibody, which is effective in psoriasis, was used in a phase II clinical trial of RRMS [116], it failed to show any therapeutic efficiency in the treated MS patients, in contrast to prior observations in EAE, where functional absence of IL12/IL23p40 fully abrogated the disease (summarized in [117]). Additional treatment attempts with cytokines (e.g. TGF- $\beta$ ), cytokine inhibitors (e.g. atacicept) and other approaches (e.g. altered peptide ligand) are mentioned in Table 1. Although the EAE models have helped to understand certain aspects of the immunopathogenesis of MS, these findings highlight that they failed to illustrate the entire complexity of the disease.

\section{Conclusions and Outlook}

Effective and unsuccessful MS therapies have further substantiated the concept of MS as a prototypic organspecific autoimmune disease, but at the same time they have underscored the notion of significant heterogeneity of disease processes in MS as well as differences in disease mechanisms between different autoimmune diseases. Neuropathologists have defined four distinct patterns of tissue injury in brain biopsy or autopsy tissue of MS patients based on characteristic signs of cellular or humoral immune components [13]. Thus, there is a need to increase efforts in further studying the highly complex disease processes underlying the different forms of MS.

Based on the current knowledge, we hypothesize that the quantitative genetic trait of MS (with different numbers of risk alleles in individual patients), and particularly genes of the HLA-DR15 haplotype (DRB1*15:01, DRB5*01:01, DQA1*01:02, DQB1*06:02), together with environmental triggers cause a peripheral activation of $\mathrm{CD}^{+} \mathrm{T}$ cells. Upon entering the CNS, $\mathrm{CD} 4^{+} \mathrm{T}$ cells start a CNS-directed autoimmune disease, with additional immune cells (i.e. CD8 ${ }^{+}$T cells, B cells and antibodies, DCs, Treg cells) playing important roles during tissue damage, local antigen presentation in the CNS (DCs) or periphery (B cells), and maintaining or not peripheral immune tolerance (Treg cells) [1]. 
In this context, it will be important to perform detailed phenotypic and functional analysis of disease-relevant adaptive immune cells and tissues from MS patients. This will include expanding our knowledge on autoantigens possibly involved in MS pathogenesis beyond investigating T cells and B cells specifically targeting the myelin antigens causing EAE. Besides examining peripheral blood T and B cells, we propose that significant efforts need to be undertaken to investigate the specificity of adaptive immune cells in the CSF and directly from the affected tissue, namely the brain and spinal cord parenchyma. Localization of $T$ and $B$ cells in these different CNS compartments and thus their migratory capacity will critically influence their contribution to MS pathogenesis.

Immune cell trafficking to the CNS is a critical hallmark of MS and strictly controlled by the BBB and the epithelial blood-cerebrospinal fluid barrier (BCSFB), which protect the CNS from the constantly changing milieu in the blood stream [118]. While CNS parenchyma in healthy individuals is completely devoid of T and B cells, the CSF space although harboring 10 to 100 -fold less cells than other sterile body fluids (e.g. synovial or pleural fluid), is characterized by the presence of a high proportion of $\mathrm{T}_{\mathrm{CM}}$ and $\mathrm{T}_{\mathrm{EM}}$ cells (summarized in [119]). This underscores that T cells routinely cross the BBB and BCSFB and enter the CSF space from where they maintain immune surveillance of the CNS. In the absence of local activation, these T cells remain separated from the CNS parenchyma by the glia limitans, which establishes a second tissue barrier that is lacking in all other organs [120]. Based on recent observations that immune-deficient mice suffer from cognitive deficits and that certain T-cell subsets even exert neuroprotective effects, it has even been proposed that CSF T cells may actively contribute to tissue homeostasis [121] and thus the term „protective autoimmunity“ was coined to describe the contribution of CNS-specific CD4 ${ }^{+} \mathrm{T}$ cells to the protection of the CNS [122]. The anatomical routes and molecular mechanisms involved in T cell trafficking into the CSF spaces during CNS immunosurveillance, and how they change during MS are still incompletely understood and need further investigation.

In this context it is however important that CSF drains from the subarachnoid space via lymphatic vessels in the nasal mucosa $[123,124,125]$ and via dural lymphatics $[126,127]$ into the deep cervical lymph nodes and hence to the extracerebral immune system. CNS antigens may thus become available to the peripheral immune system via these drainage routes. The observation by Stern et al. [128] that B cells, which populate MS brain tissue, mature in draining cervical lymph nodes supports this notion and indicates that the recognition of brainderived antigen may involve not only the above mentioned lymphatic structures, but also antigen presentation in the draining cervical lymph nodes.

Natalizumab-treated MS patients show significantly reduced counts of both $\mathrm{CD} 4^{+}$and $\mathrm{CD} 8^{+} \mathrm{T}$-cell subsets in their CSF [129], arguing that natalizumab blocks CNS entry of both, CD4 ${ }^{+}$and CD8 ${ }^{+} \mathrm{T}$-cell subsets and that reducing the CSF pool of T cells interferes with CNS immunosurveillance. The increased risk for PML observed under natalizumab therapy has supported this notion; however, it completely fails to explain how reduced CNS immune surveillance will establish a specific risk for infection to one single virus. Further insights into these mechanisms rely on continuous research with the patients' cells as outlined above. 
Understanding the anatomical routes and molecular mechanisms guiding different T-and B-cell subsets into the CNS during immunosurveillance and neuroinflammation, as well as examining their specificity and function will thus set the stage to more accurately foresee CNS specific adverse effects of the increasing numbers of therapies targeting T-cell trafficking or even depleting T cells in MS. Additionally, this will allow to identify novel therapeutic targets at the level of the brain barriers suited to specifically block CNS recruitment of destructive T cells, while leaving the migration of protective T-cell subsets into the CNS unaffected.

\section{Acknowledgements}

RM, MS and BE are supported by the Swiss National Science Foundation (Sinergia UnmetMS) and the Swiss MS Society. RM is supported of an Advanced Grant of the European Research Council. RM and MS are supported by Clinical Research Priority Project (CRPPMs) Grant of the University Zurich.

\section{Conflict of interest statement}

R. Martin is listed as co-inventor on a patent for the use of daclizumab in MS; he has received honoraria for participation on advisory boards or giving educational presentations by Novartis, Hoffmann La Roche, Biogen, Sanofi Aventis, Merck, Neuway Pharma, Cell Protect and Bionamics; he or members of his group have received unrestricted grants from Novartis and Biogen. The other authors declare no financial or commercial conflict of interest. 


\section{References}

1 Sospedra, M. and Martin, R., Immunology of multiple sclerosis. Annu Rev Immunol 2005. 23: 683-747.

2 Ciccarelli, O., Barkhof, F., Bodini, B., De Stefano, N., Golay, X., Nicolay, K., Pelletier, D., Pouwels, P. J., Smith, S. A., Wheeler-Kingshott, C. A., Stankoff, B., Yousry, T. and Miller, D. H., Pathogenesis of multiple sclerosis: insights from molecular and metabolic imaging. Lancet Neurol 2014. 13: 807-822. Noseworthy, J. H., Lucchinetti, C., Rodriguez, M. and Weinshenker, B. G., Multiple sclerosis. N Eng/ J Med 2000. 343: 938-952. Steinman, L. and Zamvil, S. S., How to successfully apply animal studies in experimental allergic encephalomyelitis to research on multiple sclerosis. Ann Neurol 2006. 60: 12-21. Martin, R., McFarland, H. F. and McFarlin, D. E., Immunological aspects of demyelinating diseases. Annu Rev Immunol 1992. 10: 153-187. Krishnamoorthy, G. and Wekerle, H., EAE: an immunologist's magic eye. Eur J Immunol 2009. 39: 2031-2035. Lassmann, H. and van Horssen, J., The molecular basis of neurodegeneration in multiple sclerosis. FEBS Lett 2011. 585: 3715-3723. Yshii, L., Gebauer, C., Bernard-Valnet, R. and Liblau, R., Neurons and T cells: Understanding this interaction for inflammatory neurological diseases. Eur J Immunol 2015. 45: 2712-2720. Hoffmann, F. and Meinl, E., B cells in multiple sclerosis: good or bad guys?: An article for 28 May 2014 - World MS Day 2014. Eur J Immunol 2014. 44: 1247-1250. Functional inflammatory profiles distinguish myelin-reactive T cells from patients with multiple sclerosis. Sci Transl Med 2015. 7: 287ra274.

Hartmann, F. J., Khademi, M., Aram, J., Ammann, S., Kockum, I., Constantinescu, C., Gran, B., Piehl, F., Olsson, T., Codarri, L. and Becher, B., Multiple sclerosis-associated IL2RA polymorphism controls GM-CSF production in human TH cells. Nat Commun 2014. 5: 5056.

Planas, R., Metz, I., Ortiz, Y., Vilarrasa, N., Jelcic, I., Salinas-Riester, G., Heesen, C., Bruck, W., Martin, R. and Sospedra, M., Central role of Th2/Tc2 lymphocytes in pattern II multiple sclerosis lesions. Ann Clin Transl Neurol 2015. 2: 875-893.

Lucchinetti, C., Bruck, W., Parisi, J., Scheithauer, B., Rodriguez, M. and Lassmann, H., Heterogeneity of multiple sclerosis lesions: implications for the pathogenesis of demyelination. Ann Neurol 2000. 47: 707-717.

Madsen, L. S., Andersson, E. C., Jansson, L., krogsgaard, M., Andersen, C. B., Engberg, J., Strominger, J. L., Svejgaard, A., Hjorth, J. P., Holmdahl, R., Wucherpfennig, K. W. and Fugger, L., A humanized model for multiple sclerosis using HLA-DR2 and a human T-cell receptor. Nat Genet 1999. 23: 343-347. Quandt, J. A., Baig, M., Yao, K., Kawamura, K., Huh, J., Ludwin, S. K., Bian, H. J., Bryant, M., Quigley, L., Nagy, Z. A., McFarland, H. F., Muraro, P. A., Martin, R. and Ito, K., Unique clinical and pathological features in HLA-DRB1*0401-restricted MBP 111-129-specific humanized TCR transgenic mice. J Exp Med 2004. 200: 223-234. F., Martin, R. and Ito, K., Myelin basic protein-specific TCR/HLA-DRB5*01:01 transgenic mice support the etiologic role of DRB5*01:01 in multiple sclerosis. J Immunol 2012. 189: 2897-2908. Bielekova, B., Goodwin, B., Richert, N., Cortese, I., Kondo, T., Afshar, G., Gran, B., Eaton, J., Antel, J., Frank, J. A., McFarland, H. F. and Martin, R., Encephalitogenic potential of the myelin basic protein peptide (amino acids 83-99) in multiple sclerosis: results of a phase II clinical trial with an altered peptide ligand. Nat Med 2000. 6: 1167-1175.

Jersild, C., Svejgaard, A. and Fog, T., HL-A antigens and multiple sclerosis. Lancet 1972. 1: 1240-1241. International Multiple Sclerosis Genetics, C., Wellcome Trust Case Control, C., Sawcer, S., Hellenthal, G., Pirinen, M., Spencer, C. C., Patsopoulos, N. A., Moutsianas, L., Dilthey, A., Su, Z., Freeman, C., Hunt, S. E., Edkins, S., Gray, E., Booth, D. R., Potter, S. C., Goris, A., Band, G., Oturai, A. B., Strange, A., Saarela, J., Bellenguez, C., Fontaine, B., Gillman, M., Hemmer, B., Gwilliam, R., Zipp, F., Jayakumar, A., Martin, R., Leslie, S., Hawkins, S., Giannoulatou, E., D'Alfonso, S., Blackburn, H., Martinelli Boneschi, F., Liddle, J., Harbo, H. F., Perez, M. L., Spurkland, A., Waller, M. J., Mycko, M. P., Ricketts, M., Comabella, M., Hammond, N., Kockum, I., McCann, O. T., Ban, M., Whittaker, P., Kemppinen, A., Weston, P., Hawkins, C., Widaa, S., Zajicek, J., Dronov, S., Robertson, N., Bumpstead, S. J., Barcellos, L. F., Ravindrarajah, R., Abraham, R., Alfredsson, L., Ardlie, K., Aubin, C., Baker, A., 
Baker, K., Baranzini, S. E., Bergamaschi, L., Bergamaschi, R., Bernstein, A., Berthele, A., Boggild, M., Bradfield, J. P., Brassat, D., Broadley, S. A., Buck, D., Butzkueven, H., Capra, R., Carroll, W. M., Cavalla, P., Celius, E. G., Cepok, S., Chiavacci, R., Clerget-Darpoux, F., Clysters, K., Comi, G., Cossburn, M., Cournu-Rebeix, I., Cox, M. B., Cozen, W., Cree, B. A., Cross, A. H., Cusi, D., Daly, M. J., Davis, E., de Bakker, P. I., Debouverie, M., D'Hooghe M, B., Dixon, K., Dobosi, R., Dubois, B., Ellinghaus, D., Genetic risk and a primary role for cell-mediated immune mechanisms in multiple sclerosis. Nature 2011. 476: 214-219. M. F., Kemppinen, A., Cotsapas, C., Shah, T. S., Spencer, C., Booth, D., Goris, A., Oturai, A., Saarela, J., Fontaine, B., Hemmer, B., Martin, C., Zipp, F., D'Alfonso, S., Martinelli-Boneschi, F., Taylor, B., Harbo, H. F., Kockum, I., Hillert, J., Olsson, T., Ban, M., Oksenberg, J. R., Hintzen, R., Barcellos, L. F., Wellcome Trust Case Control, C., International, I. B. D. G. C., Agliardi, C., Alfredsson, L., Alizadeh, M., Anderson, C., Andrews, R., Sondergaard, H. B., Baker, A., Band, G., Baranzini, S. E., Barizzone, N., Barrett, J., Bellenguez, C., Bergamaschi, L., Bernardinelli, L., Berthele, A., Biberacher, V., Binder, T. M., Blackburn, H., Bomfim, I. L., Brambilla, P., Broadley, S., Brochet, B., Brundin, L., Buck, D., Butzkueven, H., Caillier, S. J., Camu, W., Carpentier, W., Cavalla, P., Celius, E. G., Coman, I., Comi, G., Corrado, L., Cosemans, L., Cournu-Rebeix, I., Cree, B. A., Cusi, D., Damotte, V., Defer, G., Delgado, S. R., Deloukas, P., di Sapio, A., Dilthey, A. T., Donnelly, P., Dubois, B., Duddy, M., Edkins, S., Elovaara, I., Esposito, F., Evangelou, N., Fiddes, B., Field, J., Franke, A., Freeman, C., Frohlich, I. Y., Galimberti, D., Gieger, C., Gourraud, P. A., Graetz, C., Graham, A., Grummel, V., Guaschino, C., Hadjixenofontos, A., Hakonarson, H., Halfpenny, C., Hall, G., Hall, P., Hamsten, A., Harley, J., Harrower, T., Analysis of immune-related loci identifies 48 new susceptibility variants for multiple sclerosis. Nat Genet 2013. 45: 1353-1360.

Babbe, H., Roers, A., Waisman, A., Lassmann, H., Goebels, N., Hohlfeld, R., Friese, M., Schroder, R., Deckert, M., Schmidt, S., Ravid, R. and Rajewsky, K., Clonal expansions of CD8(+) T cells dominate the $T$ cell infiltrate in active multiple sclerosis lesions as shown by micromanipulation and single cell polymerase chain reaction. J Exp Med 2000. 192: 393-404. Huseby, E. S., Liggitt, D., Brabb, T., Schnabel, B., Ohlen, C. and Goverman, J., A pathogenic role for myelin-specific CD8(+) T cells in a model for multiple sclerosis. J Exp Med 2001. 194: 669-676. Suzumura, A., Silberberg, D. H. and Lisak, R. P., The expression of MHC antigens on oligodendrocytes: induction of polymorphic H-2 expression by lymphokines. J Neuroimmunol 1986. 11: 179-190. Neumann, H., Cavalie, A., Jenne, D. E. and Wekerle, H., Induction of MHC class I genes in neurons. Science 1995. 269: 549-552.

Elliott, C., Lindner, M., Arthur, A., Brennan, K., Jarius, S., Hussey, J., Chan, A., Stroet, A., Olsson, T., Willison, H., Barnett, S. C., Meinl, E. and Linington, C., Functional identification of pathogenic autoantibody responses in patients with multiple sclerosis. Brain 2012. 135: 1819-1833.

Flach, A. C., Litke, T., Strauss, J., Haberl, M., Gomez, C. C., Reindl, M., Saiz, A., Fehling, H. J., Wienands, J., Odoardi, F., Luhder, F. and Flugel, A., Autoantibody-boosted T-cell reactivation in the target organ triggers manifestation of autoimmune CNS disease. Proc Natl Acad Sci U S A 2016. 113: 3323-3328. Mathey, E. K., Derfuss, T., Storch, M. K., Williams, K. R., Hales, K., Woolley, D. R., Al-Hayani, A., Davies, S. N., Rasband, M. N., Olsson, T., Moldenhauer, A., Velhin, S., Hohlfeld, R., Meinl, E. and Linington, C., Neurofascin as a novel target for autoantibody-mediated axonal injury. J Exp Med 2007. 204: 2363-2372.

Derfuss, T., Parikh, K., Velhin, S., Braun, M., Mathey, E., Krumbholz, M., Kumpfel, T., Moldenhauer, A., Rader, C., Sonderegger, P., Pollmann, W., Tiefenthaller, C., Bauer, J., Lassmann, H., Wekerle, H., Karagogeos, D., Hohlfeld, R., Linington, C. and Meinl, E., Contactin-2/TAG-1-directed autoimmunity is identified in multiple sclerosis patients and mediates gray matter pathology in animals. Proc Natl Acad Sci U S A 2009. 106: 8302-8307.

Srivastava, R., Aslam, M., Kalluri, S. R., Schirmer, L., Buck, D., Tackenberg, B., Rothhammer, V., Chan, A., Gold, R., Berthele, A., Bennett, J. L., Korn, T. and Hemmer, B., Potassium channel KIR4.1 as an immune target in multiple sclerosis. N Engl J Med 2012. 367: 115-123. Hauser, S. L., Waubant, E., Arnold, D. L., Vollmer, T., Antel, J., Fox, R. J., Bar-Or, A., Panzara, M., Sarkar, N., Agarwal, S., Langer-Gould, A., Smith, C. H. and Group, H. T., B-cell depletion with rituximab in relapsing-remitting multiple sclerosis. N Engl J Med 2008. 358: 676-688.

Li, R., Rezk, A., Miyazaki, Y., Hilgenberg, E., Touil, H., Shen, P., Moore, C. S., Michel, L., Althekair, F., Rajasekharan, S., Gommerman, J. L., Prat, A., Fillatreau, S., Bar-Or, A. and Canadian, B. c. i. M. S. T., 
Proinflammatory GM-CSF-producing B cells in multiple sclerosis and B cell depletion therapy. Sci Transl Med 2015. 7: 310ra166.

Frischer, J. M., Weigand, S. D., Guo, Y., Kale, N., Parisi, J. E., Pirko, I., Mandrekar, J., Bramow, S., Metz, I., Bruck, W., Lassmann, H. and Lucchinetti, C. F., Clinical and pathological insights into the dynamic nature of the white matter multiple sclerosis plaque. Ann Neurol 2015. 78: 710-721. Miller, D. H., Khan, O. A., Sheremata, W. A., Blumhardt, L. D., Rice, G. P., Libonati, M. A., WillmerHulme, A. J., Dalton, C. M., Miszkiel, K. A., O'Connor, P. W. and International Natalizumab Multiple Sclerosis Trial, G., A controlled trial of natalizumab for relapsing multiple sclerosis. N Engl J Med 2003. 348: 15-23. Coles, A. J., Fox, E., Vladic, A., Gazda, S. K., Brinar, V., Selmaj, K. W., Bass, A. D., Wynn, D. R., Margolin, D. H., Lake, S. L., Moran, S., Palmer, J., Smith, M. S. and Compston, D. A., Alemtuzumab versus interferon beta-1a in early relapsing-remitting multiple sclerosis: post-hoc and subset analyses of clinical efficacy outcomes. Lancet Neurol 2011. 10: 338-348.

Kappos, L., Wiendl, H., Selmaj, K., Arnold, D. L., Havrdova, E., Boyko, A., Kaufman, M., Rose, J., Greenberg, S., Sweetser, M., Riester, K., O'Neill, G. and Elkins, J., Daclizumab HYP versus Interferon Beta-1a in Relapsing Multiple Sclerosis. N Engl J Med 2015. 373: 1418-1428. Straus Farber, R., Harel, A. and Lublin, F., Novel Agents for Relapsing Forms of Multiple Sclerosis. Annu Rev Med 2016. 67: 309-321. Jacobs, L., O'Malley, J., Freeman, A., Murawski, J. and Ekes, R., Intrathecal interferon in multiple sclerosis. Arch Neurol 1982. 39: 609-615.

Paty, D. W. and Li, D. K., Interferon beta-1b is effective in relapsing-remitting multiple sclerosis. II. $\mathrm{MRI}$ analysis results of a multicenter, randomized, double-blind, placebo-controlled trial. UBC MS/MRI Study Group and the IFNB Multiple Sclerosis Study Group. Neurology 1993. 43: 662-667.

Leppert, D., Waubant, E., Burk, M. R., Oksenberg, J. R. and Hauser, S. L., Interferon beta-1b inhibits gelatinase secretion and in vitro migration of human T cells: a possible mechanism for treatment efficacy in multiple sclerosis. Ann Neurol 1996. 40: 846-852. Stuve, O., Dooley, N. P., Uhm, J. H., Antel, J. P., Francis, G. S., Williams, G. and Yong, V. W., Interferon beta-1b decreases the migration of T lymphocytes in vitro: effects on matrix metalloproteinase-9. Ann Neurol 1996. 40: 853-863.

Uhm, J. H., Dooley, N. P., Stuve, O., Francis, G. S., Duquette, P., Antel, J. P. and Yong, V. W., Migratory behavior of lymphocytes isolated from multiple sclerosis patients: effects of interferon beta-1b therapy. Ann Neurol 1999. 46: 319-324. reduces interferon gamma-induced antigen-presenting capacity of human glial and B cells. $J$ Neuroimmunol 1995. 61: 17-25.

Kozovska, M. E., Hong, J., Zang, Y. C., Li, S., Rivera, V. M., Killian, J. M. and Zhang, J. Z., Interferon beta induces T-helper 2 immune deviation in MS. Neurology 1999. 53: 1692-1697.

Dhib-Jalbut, S. and Marks, S., Interferon-beta mechanisms of action in multiple sclerosis. Neurology 2010. 74 Suppl 1: S17-24.

Ristori, G., Montesperelli, C., Gasperini, C., Battistini, L., Borsellino, G., Buttinelli, C., Cannoni, S., Perna, A., Pozzilli, C. and Salvetti, M., T cell response to myelin basic protein before and after treatment with interferon beta in multiple sclerosis. J Neuroimmunol 1999. 99: 91-96.

Teitelbaum, D., Webb, C., Bree, M., Meshorer, A., Arnon, R. and Sela, M., Suppression of experimental allergic encephalomyelitis in Rhesus monkeys by a synthetic basic copolymer. Clin Immunol Immunopathol 1974. 3: 256-262.

Johnson, K. P., Brooks, B. R., Cohen, J. A., Ford, C. C., Goldstein, J., Lisak, R. P., Myers, L. W., Panitch, H. S., Rose, J. W., Schiffer, R. B., Vollmer, T., Weiner, L. P., Wolinsky, J. S. and Copolymer 1 Multiple Sclerosis Study, G., Copolymer 1 reduces relapse rate and improves disability in relapsing-remitting multiple sclerosis: results of a phase III multicenter, double-blind, placebo-controlled trial. 1995. Neurology 2001. 57: S16-24.

48 Racke, M. K., Martin, R., McFarland, H. and Fritz, R. B., Copolymer-1-induced inhibition of antigenspecific T cell activation: interference with antigen presentation. J Neuroimmunol 1992. 37: 75-84. Aharoni, R., Teitelbaum, D., Sela, M. and Arnon, R., Copolymer 1 induces T cells of the T helper type 2 that crossreact with myelin basic protein and suppress experimental autoimmune encephalomyelitis. Proc Natl Acad Sci U S A 1997. 94: 10821-10826. and interactions of copolymer-I and beta-interferon 1a in multiple sclerosis. J Neuroimmunol 2003. 
137: 144-153.

Karandikar, N. J., Crawford, M. P., Yan, X., Ratts, R. B., Brenchley, J. M., Ambrozak, D. R., LovettRacke, A. E., Frohman, E. M., Stastny, P., Douek, D. C., Koup, R. A. and Racke, M. K., Glatiramer acetate (Copaxone) therapy induces CD8(+) T cell responses in patients with multiple sclerosis. J Clin Invest 2002. 109: 641-649.

Weber, M. S., Prod'homme, T., Youssef, S., Dunn, S. E., Rundle, C. D., Lee, L., Patarroyo, J. C., Stuve, O., Sobel, R. A., Steinman, L. and Zamvil, S. S., Type II monocytes modulate T cell-mediated central nervous system autoimmune disease. Nat Med 2007. 13: 935-943.

Gran, B., Tranquill, L. R., Chen, M., Bielekova, B., Zhou, W., Dhib-Jalbut, S. and Martin, R., Mechanisms of immunomodulation by glatiramer acetate. Neurology 2000. 55: 1704-1714. Dhib-Jalbut, S., Chen, M., Said, A., Zhan, M., Johnson, K. P. and Martin, R., Glatiramer acetatereactive peripheral blood mononuclear cells respond to multiple myelin antigens with a Th2-biased phenotype. J Neuroimmunol 2003. 140: 163-171.

Ziemssen, T., Kumpfel, T., Schneider, H., Klinkert, W. E., Neuhaus, O. and Hohlfeld, R., Secretion of brain-derived neurotrophic factor by glatiramer acetate-reactive T-helper cell lines: Implications for multiple sclerosis therapy. J Neurol Sci 2005. 233: 109-112.

Yednock, T. A., Cannon, C., Fritz, L. C., Sanchez-Madrid, F., Steinman, L. and Karin, N., Prevention of experimental autoimmune encephalomyelitis by antibodies against alpha 4 beta 1 integrin. Nature 1992. 356: 63-66. development of experimental autoimmune encephalomyelitis in the mouse requires alpha4-integrin but not alpha4beta7-integrin. J Clin Invest 1998. 102: 2096-2105.

Baldwin, K. J. and Hogg, J. P., Progressive multifocal leukoencephalopathy in patients with multiple sclerosis. Curr Opin Neurol 2013. 26: 318-323.

Major, E. O., Progressive multifocal leukoencephalopathy in patients on immunomodulatory therapies. Annu Rev Med 2010. 61: 35-47.

Aly, L., Yousef, S., Schippling, S., Jelcic, I., Breiden, P., Matschke, J., Schulz, R., Bofill-Mas, S., Jones, L., Demina, V., Linnebank, M., Ogg, G., Girones, R., Weber, T., Sospedra, M. and Martin, R., Central role of JC virus-specific CD4+ lymphocytes in progressive multi-focal leucoencephalopathy-immune reconstitution inflammatory syndrome. Brain 2011. 134: 2687-2702.

Planas, R., Jelcic, I., Schippling, S., Martin, R. and Sospedra, M., Natalizumab treatment perturbs memory- and marginal zone-like B-cell homing in secondary lymphoid organs in multiple sclerosis. Eur J Immunol 2012. 42: 790-798.

Jelcic, I., Jelcic, I., Kempf, C., Largey, F., Planas, R., Schippling, S., Budka, H., Sospedra, M. and Martin, R., Mechanisms of immune escape in central nervous system infection with neurotropic JC virus variant. Ann Neurol 2016. 79: 404-418.

Brinkmann, V., Billich, A., Baumruker, T., Heining, P., Schmouder, R., Francis, G., Aradhye, S. and Burtin, P., Fingolimod (FTY720): discovery and development of an oral drug to treat multiple sclerosis. Nat Rev Drug Discov 2010. 9: 883-897. Blaho, V. A. and Hla, T., An update on the biology of sphingosine 1-phosphate receptors. J Lipid Res 2014. 55: 1596-1608. novel immunosuppressant, FTY720, with a unique mechanism of action, induces long-term graft acceptance in rat and dog allotransplantation. Transplantation 1996. 61: 200-205. Fujino, M., Funeshima, N., Kitazawa, Y., Kimura, H., Amemiya, H., Suzuki, S. and Li, X. K., Amelioration of experimental autoimmune encephalomyelitis in Lewis rats by FTY720 treatment. $J$ Pharmacol Exp Ther 2003. 305: 70-77.

Yanagawa, Y., Masubuchi, Y, and Chiba, K., FTY720, a novel immunosuppressant, induces sequestration of circulating mature lymphocytes by acceleration of lymphocyte homing in rats, III. Increase in frequency of CD62L-positive T cells in Peyer's patches by FTY720-induced lymphocyte homing. Immunology 1998. 95: 591-594. 
Pfender, N., Jelcic, I., Linnebank, M., Schwarz, U. and Martin, R., Reactivation of herpesvirus under fingolimod: A case of severe herpes simplex encephalitis. Neurology 2015. 84: 2377-2378.

Gyang, T. V., Hamel, J., Goodman, A. D., Gross, R. A. and Samkoff, L., Fingolimod-associated PML in a patient with prior immunosuppression. Neurology 2016. 86: 1843-1845.

O'Connor, P. W., Li, D., Freedman, M. S., Bar-Or, A., Rice, G. P., Confavreux, C., Paty, D. W., Stewart, J. A., Scheyer, R., Teriflunomide Multiple Sclerosis Trial, G. and University of British Columbia, M. S.

M. R. I. R. G., A Phase II study of the safety and efficacy of teriflunomide in multiple sclerosis with relapses. Neurology 2006. 66: 894-900.

O'Connor, P., Wolinsky, J. S., Confavreux, C., Comi, G., Kappos, L., Olsson, T. P., Benzerdjeb, H., Truffinet, P., Wang, L., Miller, A., Freedman, M. S. and Group, T. T., Randomized trial of oral teriflunomide for relapsing multiple sclerosis. N Engl J Med 2011. 365: 1293-1303.

Gold, R., Kappos, L., Arnold, D. L., Bar-Or, A., Giovannoni, G., Selmaj, K., Tornatore, C., Sweetser, M. T., Yang, M., Sheikh, S. I., Dawson, K. T. and Investigators, D. S., Placebo-controlled phase 3 study of oral BG-12 for relapsing multiple sclerosis. N Engl J Med 2012. 367: 1098-1107. Bar-Or, A., Pachner, A., Menguy-Vacheron, F., Kaplan, J. and Wiendl,
mechanism of action in multiple sclerosis. Drugs 2014. 74: 659-674.

Dubiel, W. and Happle, R., [Experimental treatment with fumaric acid monoethylester in psoriasis vulgaris]. Z Haut Geschlechtskr 1972. 47: 545-550.

Ghoreschi, K., Bruck, J., Kellerer, C., Deng, C., Peng, H., Rothfuss, O., Hussain, R. Z., Gocke, A. R., Respa, A., Glocova, I., Valtcheva, N., Alexander, E., Feil, S., Feil, R., Schulze-Osthoff, K., Rupec, R. A., Lovett-Racke, A. E., Dringen, R., Racke, M. K. and Rocken, M., Fumarates improve psoriasis and multiple sclerosis by inducing type II dendritic cells. J Exp Med 2011. 208: 2291-2303.

Linker, R. A., Lee, D. H., Ryan, S., van Dam, A. M., Conrad, R., Bista, P., Zeng, W., Hronowsky, X., Buko, A., Chollate, S., Ellrichmann, G., Bruck, W., Dawson, K., Goelz, S., Wiese, S., Scannevin, R. H., Lukashev, M. and Gold, R., Fumaric acid esters exert neuroprotective effects in neuroinflammation via activation of the Nrf2 antioxidant pathway. Brain 2011. 134: 678-692.

Lundy, S. K., Wu, Q., Wang, Q., Dowling, C. A., Taitano, S. H., Mao, G. and Mao-Draayer, Y., Dimethyl fumarate treatment of relapsing-remitting multiple sclerosis influences B-cell subsets. Neurol Neuroimmunol Neuroinflamm 2016. 3: e211.

81 Rosenkranz, T., Novas, M. and Terborg, C., PML in a patient with lymphocytopenia treated with dimethyl fumarate. N Engl J Med 2015. 372: 1476-1478.

Heit, W., Bunjes, D., Wiesneth, M., Schmeiser, T., Arnold, R., Hale, G., Waldmann, H. and Heimpel, H., Ex vivo T-cell depletion with the monoclonal antibody Campath-1 plus human complement effectively prevents acute graft-versus-host disease in allogeneic bone marrow transplantation. $\mathrm{Br} J$ Haematol 1986. 64: 479-486.

Osterborg, A., Fassas, A. S., Anagnostopoulos, A., Dyer, M. J., Catovsky, D. and Mellstedt, H., Humanized CD52 monoclonal antibody Campath-1H as first-line treatment in chronic lymphocytic leukaemia. Br J Haematol 1996. 93: 151-153.

Coles, A., Deans, J. and Compston, A., Campath-1H treatment of multiple sclerosis: lessons from the bedside for the bench. Clin Neurol Neurosurg 2004. 106: 270-274.

Cox, A. L., Thompson, S. A., Jones, J. L., Robertson, V. H., Hale, G., Waldmann, H., Compston, D. A. and Coles, A. J., Lymphocyte homeostasis following therapeutic lymphocyte depletion in multiple sclerosis. Eur J Immunol 2005. 35: 3332-3342.

Cossburn, M., Pace, A. A., Jones, J., Ali, R., Ingram, G., Baker, K., Hirst, C., Zajicek, J., Scolding, N., Boggild, M., Pickersgill, T., Ben-Shlomo, Y., Coles, A. and Robertson, N. P., Autoimmune disease after alemtuzumab treatment for multiple sclerosis in a multicenter cohort. Neurology 2011. 77: 573-579. Hauser, S. L., Comi, G. C., Hartung, H.-P., Selmaj, K., Traboulsee, A., Bar-Or, A., Arnold, D. L., Klingelschmitt, G., Kakarieka, A., Lublin, F., Garren, H. and Kappos, L., Efficacy and safety of ocrelizumab in relapsing multiple sclerosis - results of the interferon-beta-1a-controlled, double-blind, Phase III OPERA I and II studies. ECTRIMS 20152015.

Sorensen, P. S., Lisby, S., Grove, R., Derosier, F., Shackelford, S., Havrdova, E., Drulovic, J. and Filippi, M., Safety and efficacy of ofatumumab in relapsing-remitting multiple sclerosis: a phase 2 study. Neurology 2014. 82: 573-581.

Hawker, K., O'Connor, P., Freedman, M. S., Calabresi, P. A., Antel, J., Simon, J., Hauser, S., Waubant, E., Vollmer, T., Panitch, H., Zhang, J., Chin, P., Smith, C. H. and group, O. t., Rituximab in patients with primary progressive multiple sclerosis: results of a randomized double-blind placebo-controlled 
multicenter trial. Ann Neurol 2009. 66: 460-471.

Montalban, X., Hemmer, B., Rammohan, K., Giovannoni, G., de Seze, J., Bar-Or, A., Arnold, D. L., Sauter, A., Kakarieka, A., Masterman, D., Chin, P., Garren, H. and Wolinsky, J. S., Efficacy and safety of ocrelizumab in primary progressive multiple sclerosis - results of the placebo-controlled, doubleblind, Phase III ORATORIO study. ECTRIMS 20152015.

Serafini, B., Rosicarelli, B., Franciotta, D., Magliozzi, R., Reynolds, R., Cinque, P., Andreoni, L., Trivedi, P., Salvetti, M., Faggioni, A. and Aloisi, F., Dysregulated Epstein-Barr virus infection in the multiple sclerosis brain. J Exp Med 2007. 204: 2899-2912.

Lucchinetti, C. F., Popescu, B. F., Bunyan, R. F., Moll, N. M., Roemer, S. F., Lassmann, H., Bruck, W., Parisi, J. E., Scheithauer, B. W., Giannini, C., Weigand, S. D., Mandrekar, J. and Ransohoff, R. M., Inflammatory cortical demyelination in early multiple sclerosis. N Engl J Med 2011. 365: 2188-2197. Vincenti, F., Kirkman, R., Light, S., Bumgardner, G., Pescovitz, M., Halloran, P., Neylan, J., Wilkinson, A., Ekberg, H., Gaston, R., Backman, L. and Burdick, J., Interleukin-2-receptor blockade with daclizumab to prevent acute rejection in renal transplantation. Daclizumab Triple Therapy Study Group. N Engl J Med 1998. 338: 161-165.

Waldmann, T. A., The IL-2/IL-2 receptor system: a target for rational immune intervention. Immunol Today 1993. 14: 264-270.

Nussenblatt, R. B., Fortin, E., Schiffman, R., Rizzo, L., Smith, J., Van Veldhuisen, P., Sran, P., Yaffe, A., Goldman, C. K., Waldmann, T. A. and Whitcup, S. M., Treatment of noninfectious intermediate and posterior uveitis with the humanized anti-Tac mAb: a phase I/II clinical trial. Proc Natl Acad Sci U S A 1999. 96: 7462-7466.

Bielekova, B., Richert, N., Howard, T., Blevins, G., Markovic-Plese, S., McCartin, J., Frank, J. A., Wurfel, J., Ohayon, J., Waldmann, T. A., McFarland, H. F. and Martin, R., Humanized anti-CD25 (daclizumab) inhibits disease activity in multiple sclerosis patients failing to respond to interferon beta. Proc Natl Acad Sci U S A 2004. 101: 8705-8708.

Bielekova, B., Catalfamo, M., Reichert-Scrivner, S., Packer, A., Cerna, M., Waldmann, T. A., McFarland, H., Henkart, P. A. and Martin, R., Regulatory CD56(bright) natural killer cells mediate immunomodulatory effects of IL-2Ralpha-targeted therapy (daclizumab) in multiple sclerosis. Proc Natl Acad Sci U S A 2006. 103: 5941-5946.

Wuest, S. C., Edwan, J. H., Martin, J. F., Han, S., Perry, J. S., Cartagena, C. M., Matsuura, E., Maric, D., Waldmann, T. A. and Bielekova, B., A role for interleukin-2 trans-presentation in dendritic cellmediated T cell activation in humans, as revealed by daclizumab therapy. Nat Med 2011. 17: 604-609. Perry, J. S., Han, S., Xu, Q., Herman, M. L., Kennedy, L. B., Csako, G. and Bielekova, B., Inhibition of LTi cell development by CD25 blockade is associated with decreased intrathecal inflammation in multiple sclerosis. Sci Transl Med 2012. 4: 145ra106.

100 Gross, C. C., Schulte-Mecklenbeck, A., Runzi, A., Kuhlmann, T., Posevitz-Fejfar, A., Schwab, N., Schneider-Hohendorf, T., Herich, S., Held, K., Konjevic, M., Hartwig, M., Dornmair, K., Hohlfeld, R., Ziemssen, T., Klotz, L., Meuth, S. G. and Wiendl, H., Impaired NK-mediated regulation of T-cell activity in multiple sclerosis is reconstituted by IL-2 receptor modulation. Proc Natl Acad Sci U S A 2016. 113: E2973-2982.

Tokuda, Y., Ohta, M., Okumura, A., Kuge, S., Kubota, M., Tajima, T. and Mitomi, T., High-dose chemotherapy with autologous hematopoietic stem-cell transplantation in breast cancer. Cancer Chemother Pharmacol 1997. 40 Suppl: S94-99.

102 Mancardi, G. and Saccardi, R., Autologous haematopoietic stem-cell transplantation in multiple sclerosis. Lancet Neurol 2008. 7: 626-636.

Mancardi, G. L., Sormani, M. P., Gualandi, F., Saiz, A., Carreras, E., Merelli, E., Donelli, A., Lugaresi, A., Di Bartolomeo, P., Rottoli, M. R., Rambaldi, A., Amato, M. P., Massacesi, L., Di Gioia, M., Vuolo, L., Curro, D., Roccatagliata, L., Filippi, M., Aguglia, U., lacopino, P., Farge, D., Saccardi, R., Astims Haemato-Neurological Collaborative Group, O. b. o. t. A. D. W. P. o. t. E. G. f. B., Marrow, T., Blood, A. H.-N. C. G. O. b. o. t. A. D. W. P. A. o. t. E. G. f. and Marrow Transplantation, E., Autologous hematopoietic stem cell transplantation in multiple sclerosis: a phase II trial. Neurology 2015. 84: 981 988.

104 Muraro, P. A., Pasquini, M. , Atkins, H., Bowen, J., Farge, D., Fassas, A., Freedman, M. S., Georges, G. E., Gualandi, F., Hamerschlak, N., Havrdova, E., Kimiskidis, V. K., Kozak, T., Mancardi, G. L., Massacesi, L., Moraes, D., Nash, R. A., Pavletic, S., Ouyang, J., Rovira, M., Saiz, A., Simoes, B., Trněný, M., Zhu, L., Zhong, X., Badoglio, M., Sormani, M. P., Saccardi, R. and Group, M.-A. L.-T. O. S., Long term outcomes after autologous hematopoietic stem cell transplantation for treatment of MS. 
ECTRIMS 20152015.

Atkins, H. L., Bowman, M., Allan, D., Anstee, G., Arnold, D. L., Bar-Or, A., Bence-Bruckler, I., Birch, P., Bredeson, C., Chen, J., Fergusson, D., Halpenny, M., Hamelin, L., Huebsch, L., Hutton, B., Laneuville, P., Lapierre, Y., Lee, H., Martin, L., McDiarmid, S., O'Connor, P., Ramsay, T., Sabloff, M., Walker, L. and Freedman, M. S., Immunoablation and autologous haemopoietic stem-cell transplantation for aggressive multiple sclerosis: a multicentre single-group phase 2 trial. Lancet 2016.

Muraro, P. A., Douek, D. C., Packer, A., Chung, K., Guenaga, F. J., Cassiani-Ingoni, R., Campbell, C., Memon, S., Nagle, J. W., Hakim, F. T., Gress, R. E., McFarland, H. F., Burt, R. K. and Martin, R., Thymic output generates a new and diverse TCR repertoire after autologous stem cell transplantation in multiple sclerosis patients. J Exp Med 2005. 201: 805-816.

107 Abrahamsson, S. V., Angelini, D. F., Dubinsky, A. N., Morel, E., Oh, U., Jones, J. L., Carassiti, D., Reynolds, R., Salvetti, M., Calabresi, P. A., Coles, A. J., Battistini, L., Martin, R., Burt, R. K. and Muraro, P. A., Non-myeloablative autologous haematopoietic stem cell transplantation expands regulatory cells and depletes IL-17 producing mucosal-associated invariant T cells in multiple sclerosis. Brain 2013. 136: 2888-2903.

108 Baker, D., Butler, D., Scallon, B. J., O'Neill, J. K., Turk, J. L. and Feldmann, M., Control of established experimental allergic encephalomyelitis by inhibition of tumor necrosis factor (TNF) activity within the central nervous system using monoclonal antibodies and TNF receptor-immunoglobulin fusion proteins. Eur J Immunol 1994. 24: 2040-2048.

109 Sharief, M. K. and Hentges, R., Association between tumor necrosis factor-alpha and disease progression in patients with multiple sclerosis. N Engl J Med 1991. 325: 467-472.

110 TNF neutralization in MS: results of a randomized, placebo-controlled multicenter study. The Lenercept Multiple Sclerosis Study Group and The University of British Columbia MS/MRI Analysis Group. Neurology 1999. 53: 457-465.

111 Sicotte, N. L. and Voskuhl, R. R., Onset of multiple sclerosis associated with anti-TNF therapy. Neurology 2001. 57: 1885-1888.

112 Codarri, L., Fontana, A. and Becher, B., Cytokine networks in multiple sclerosis: lost in translation. Curr Opin Neurol 2010. 23: 205-211.

113 Panitch, H. S., Hirsch, R. L., Haley, A. S. and Johnson, K. P., Exacerbations of multiple sclerosis in patients treated with gamma interferon. Lancet 1987. 1: 893-895.

114 Lin, W., Kemper, A., Dupree, J. L., Harding, H. P., Ron, D. and Popko, B., Interferon-gamma inhibits central nervous system remyelination through a process modulated by endoplasmic reticulum stress. Brain 2006. 129: 1306-1318.

115 Kroenke, M. A., Carlson, T. J., Andjelkovic, A. V. and Segal, B. M., IL-12- and IL-23-modulated T cells induce distinct types of EAE based on histology, CNS chemokine profile, and response to cytokine inhibition. J Exp Med 2008. 205: 1535-1541.

116 Segal, B. M., Constantinescu, C. S., Raychaudhuri, A., Kim, L., Fidelus-Gort, R., Kasper, L. H. and Ustekinumab, M. S. I., Repeated subcutaneous injections of IL12/23 p40 neutralising antibody, ustekinumab, in patients with relapsing-remitting multiple sclerosis: a phase II, double-blind, placebocontrolled, randomised, dose-ranging study. Lancet Neurol 2008. 7: 796-804.

117 Croxford, A. L., Mair, F. and Becher, B., IL-23: one cytokine in control of autoimmunity. Eur J Immunol 2012. 42: 2263-2273.

118 Engelhardt, B. and Sorokin, L., The blood-brain and the blood-cerebrospinal fluid barriers: function and dysfunction. Semin Immunopathol 2009. 31: 497-511.

119 Ransohoff, R. M. and Engelhardt, B., The anatomical and cellular basis of immune surveillance in the central nervous system. Nat Rev Immunol 2012. 12: 623-635.

120 Owens, T., Bechmann, I. and Engelhardt, B., Perivascular spaces and the two steps to neuroinflammation. J Neuropathol Exp Neurol 2008. 67: 1113-1121.

121 Ellwardt, E., Walsh, J. T., Kipnis, J. and Zipp, F., Understanding the Role of T Cells in CNS Homeostasis. Trends Immunol 2016. 37: 154-165.

122 Deczkowska, A., Baruch, K. and Schwartz, M., Type I/II Interferon Balance in the Regulation of Brain Physiology and Pathology. Trends Immunol 2016. 37: 181-192.

123 Cserr, H.F., Harling-Berg, C.J. and Knopf P.M., Drainage of brain extracellular fluid into blood and deep cervical lymph and its immunological significance. Brain Pathology 1992. 2:269-276.

124 Kida, S., Pantazis, A. and Weller, R.O., CSF drains directly from the subarachnoid space into nasal lymphatics in the rat. Anatomy, histology and immunological significance. Neuropathol Appl Neurobiol 1993. 19:480-488. 
Johnston, M., Zakharov, A., Papaiconomou, C., Salmasi, G. and Armstrong, D., (2004) Evidence of connections between cerebrospinal fluid and nasal lymphatic vessels in humans, non-human primates and other mammalian species. Cerebrospinal Fluid Research 2004. 1:2-15

126 Louveau, A., Smirnov, I., Keyes, T. J., Eccles, J. D., Rouhani, S. J., Peske, J. D., Derecki, N. C., Castle, D., Mandell, J. W., Lee, K. S., Harris, T. H. and Kipnis, J., Structural and functional features of central nervous system lymphatic vessels. Nature 2015. 523: 337-341.

127 Aspelund, A., Antila, S., Proulx, S. T., Karlsen, T. V., Karaman, S., Detmar, M., Wiig, H. and Alitalo, K., A dural lymphatic vascular system that drains brain interstitial fluid and macromolecules. J Exp Med 2015. 212: 991-999.

128 Stern, J. N., Yaari, G., Vander Heiden, J. A., Church, G., Donahue, W. F., Hintzen, R. Q., Huttner, A. J., Laman, J. D., Nagra, R. M., Nylander, A., Pitt, D., Ramanan, S., Siddiqui, B. A., Vigneault, F., Kleinstein, S. H., Hafler, D. A. and O'Connor, K. C., B cells populating the multiple sclerosis brain mature in the draining cervical lymph nodes. Sci Transl Med 2014. 6: 248ra107.

129 Alvermann, S., Hennig, C., Stuve, O., Wiendl, H. and Stangel, M., Immunophenotyping of cerebrospinal fluid cells in multiple sclerosis: in search of biomarkers. JAMA Neurol 2014. 71: 905-912. 


\section{Figure Legends}

Figure 1. Schematic representation of the putative cellular and molecular therapeutic targets used in the MS treatment .

(Left) Cellular and molecular targets in the periphery (lymph nodes, bone marrow and the respective immune cells). (Center) The endothelial BBB (red endothelial cells) at the postcapillary venule level with a perivascular space and the glia limitans including astrocytes (green). (Right) Inflamed CNS parenchyma with a neuron (yellow) and its myelinated axon and the oligodendrocyte (blue) is shown, in addition to infiltrating immune cells (APC, Th1, Th2, Th17 and macrophages). Immune cell interactions are shown with two headed black arrows, red arrows indicate therapeutic targets and T shaped lines (red) indicate blocking of pathways. Cells depleted by monoclonal antibodies are indicated with the gray shade around the respective cells target. Abbreviations: aHSCT, autologous hematopoietic stem cells transplantation; FTY720, Fingolimod; NTZ, Natalizumab; IFN $\beta$, Interferon $\beta$; DMF, Dimethylfumarate; GA, Glatiramer Acetate; APC, antigen presenting cell; BBB, blood-brain barrier; CNS, central nervous system, $P C=$ plasma cell, $M \Phi$-macrophage 
Table 1

Table 1: Treatments tested for MS: efficacy, mechanisms of action, general and specific side effects and lessons learnt.

\begin{tabular}{|c|c|c|c|c|}
\hline Treatment & Efficacy in MS & Main mechanism/s of action & $\begin{array}{l}\text { Important side effects/findings in } \\
\text { MS }\end{array}$ & Lessons learnt/questions \\
\hline $\begin{array}{l}\text { Autologous } \\
\text { hematopoietic stem } \\
\text { cell transplantation } \\
\text { (aHSCT) }\end{array}$ & Very High & $\begin{array}{l}\text { Removes the entire adaptive immune system } \\
\text { by the conditioning regimen and re- } \\
\text { establishes a new T cell repertoire from } \\
\text { CD34+ hematopoietic precursor cells }\end{array}$ & $\begin{array}{l}\text { Treatment-related mortality due } \\
\text { to infections immediately post- } \\
\text { transplantation approximately } \\
0.5-1 \% \text {; only suited for very active } \\
\text { patients; not approved yet }\end{array}$ & $\begin{array}{l}\text { Removes a pathogenic T cell repertoire; } \\
\text { thymic function is induced; new T cell } \\
\text { repertoire is established; effects on the B } \\
\text { cell repertoire/ antibodies less clear }\end{array}$ \\
\hline $\begin{array}{l}\text { Anti- } \square \text {-ntegrins } \\
\text { (natalizumab) }\end{array}$ & High & $\begin{array}{c}\text { Blocks entry of activated T cells/immune cells } \\
\text { into the CNS (CD4+>>CD8+ T cells); releases } \\
\text { certain B cell maturation stages and bone } \\
\text { marrow precursor cells into the peripheral } \\
\text { blood }\end{array}$ & $\begin{array}{l}\text { Very well tolerated, but }>600 \\
\text { cases of PML ( }>20 \% \text { with fatal } \\
\text { outcome); without major risks in } \\
\text { JCV negative individuals }\end{array}$ & $\begin{array}{l}\text { Intervention with specific steps of } \\
\text { immune response and target organ } \\
\text { surveillance can lead to problems with } \\
\text { very specific pathogens and the } \\
\text { complications associated with them; high } \\
\text { efficacy due to interference with a critical } \\
\text { step in MS pathogenesis }\end{array}$ \\
\hline $\begin{array}{c}\text { Anti-CD52 } \\
\text { (alemtuzumab) }\end{array}$ & High & $\begin{array}{l}\text { Elimination of large fractions of T- and B cells; } \\
\text { among them pathogenic T- and B cells; only } \\
\text { few therapy cycles needed; not clear, which } \\
\text { treatments could be used after alemtuzumab }\end{array}$ & $\begin{array}{l}30-40 \% \text { of patients develop } \\
\text { secondary autoimmune diseases; } \\
\text { acute infusion reactions due to } \\
\text { cell lysis }\end{array}$ & $\begin{array}{l}\text { Reasons for the induction of secondary } \\
\text { autoimmune diseases not understood; } \\
\text { long term effects of cell depletion not } \\
\text { known }\end{array}$ \\
\hline $\begin{array}{l}\text { Anti-CD20* } \\
\text { (rituximab, } \\
\text { ocrelizumab, } \\
\text { ofatumumab) }\end{array}$ & High & $\begin{array}{l}\text { Depletes a large part of the B cell lineages; } \\
\text { removes pro-inflammatory B cells and their } \\
\text { antigen-presenting function; role of } \\
\text { antibodies in the response to this treatment } \\
\text { less clear }\end{array}$ & $\begin{array}{c}\text { Acute infusion reactions; drug } \\
\text { sensitization; PML (but so far only } \\
\text { in other autoimmune diseases); } \\
\text { others }\end{array}$ & $\begin{array}{l}\text { Mechanism of its high efficacy in MS not } \\
\text { fully understood yet, but most likely due } \\
\text { to inhibition of antigen-presenting } \\
\text { function of B cells; first approach with } \\
\text { activity in PPMS }\end{array}$ \\
\hline
\end{tabular}




\begin{tabular}{|c|c|c|c|c|}
\hline Treatment & Efficacy in MS & Main mechanism/s of action & $\begin{array}{c}\text { Important side effects/findings in } \\
\text { MS }\end{array}$ & Lessons learnt/questions \\
\hline $\begin{array}{c}\text { Anti-CD25* } \\
\text { (daclizumab-Hyp) }\end{array}$ & Moderate/High & $\begin{array}{l}\text { Induces the expansion of immunoregulatory } \\
\text { NK (CD56 } \\
\text { bright }) \text { cells; inhibition of T cell } \\
\text { activation via blocking CD25 on DCs; others }\end{array}$ & $\begin{array}{l}\text { Skin reactions; liver enzyme } \\
\text { elevation; upper respiratory } \\
\text { infections }\end{array}$ & $\begin{array}{l}\text { Blocking/knocking out IL-2 or its } \\
\text { components in mouse models led to } \\
\text { severe autoimmunity or } \\
\text { immunodeficiency; CD56 }{ }^{\text {bright }} \mathrm{NK} \text { cells do } \\
\text { not exist in mice }\end{array}$ \\
\hline $\begin{array}{l}\text { Fingolimod } \\
\text { (unspecific S1P-R } \\
\text { agonist/functional } \\
\text { antagonist) }\end{array}$ & Moderate & $\begin{array}{l}\text { Traps naive and central memory T cells in } \\
\text { lymph nodes; effects on many other cells and } \\
\text { tissues including the BBB due to expression of } \\
\text { S1P receptors }\end{array}$ & $\begin{array}{l}\text { Lymphopenia; macular edema; } \\
\text { pre-cancerous skin lesions; drop in } \\
\text { blood pressure and heart rate; } \\
\text { lymphopenia; PML (rare); others }\end{array}$ & $\begin{array}{l}\text { The immunologic effects of this } \\
\text { compound causes an albeit subtle } \\
\text { compromise of immune control of } \\
\text { persistent/latent infection with HSV-1 and } \\
\text { VZV; a few fatal cases have been reported }\end{array}$ \\
\hline Dimethylfumarate & Moderate & $\begin{array}{l}\text { Th1-Th2 shift by modulating DC function; anti- } \\
\text { oxidative activity via Nrf2 induction; inhibition } \\
\text { of NF-KB-induced genes }\end{array}$ & $\begin{array}{l}\text { Gastrointestinal side effects; flush; } \\
\text { in some patients long- lasting } \\
\text { lymphopenia; elevation of liver } \\
\text { enzymes; PML (rare); others }\end{array}$ & $\begin{array}{l}\text { Works well in psoriasis; reason of long- } \\
\text { lasting lymphopenias not known }\end{array}$ \\
\hline IFN- $\beta$ & Low/Moderate & $\begin{array}{l}\text { Inhibition of matrix metalloproteases; Th1- } \\
\text { Th2 shift; influence on antigen presentation; } \\
\text { antiviral activities (relevant for the treatment } \\
\text { of MS?); others }\end{array}$ & $\begin{array}{c}\text { Very well tolerated; skin reactions; } \\
\text { flu-like symptoms transient liver } \\
\text { enzyme increase }\end{array}$ & $\begin{array}{c}\text { This type I interferon has multiple } \\
\text { immunomodulatory effects besides its } \\
\text { antiviral activities }\end{array}$ \\
\hline Glatiramer-acetate & Low/Moderate & $\begin{array}{c}\text { Affects antigen presentation; Th1-Th2 shift; } \\
\text { induces neurotrophic factors and CD8+ Tregs; } \\
\text { others }\end{array}$ & $\begin{array}{l}\text { Very well tolerated; flush; } \\
\text { lipoatrophy at injection sites }\end{array}$ & $\begin{array}{l}\text { Peptidic mixture that was developed to } \\
\text { induce EAE; effects are similar to those of } \\
\text { altered peptide ligands }\end{array}$ \\
\hline Teriflunomide & Low/Moderate & $\begin{array}{l}\text { Inhibition of dihyroorotate-synthetase; } \\
\text { inhibition of activated/growing cells }\end{array}$ & $\begin{array}{l}\text { Nausea, diarrhea, alopecia, low } \\
\text { neutrophils; liver enzyme } \\
\text { elevation; hypertension; } \\
\text { teratogenic }\end{array}$ & $\begin{array}{l}\text { Metabolite of leflunomide; which is in use } \\
\text { in rheumatoid arthritis }\end{array}$ \\
\hline
\end{tabular}




\begin{tabular}{|c|c|c|c|c|}
\hline Treatment & Efficacy in MS & Main mechanism/s of action & $\begin{array}{l}\text { Important side effects/findings in } \\
\text { MS }\end{array}$ & Lessons learnt/questions \\
\hline IFN- $\gamma$ & $\begin{array}{l}\text { Worsened } \\
\text { disease }\end{array}$ & $\begin{array}{l}\text { Primary Th1 cytokine; given with the idea of } \\
\text { mediating anti-viral effects; induces } \\
\text { proinflammatory immune reactions }\end{array}$ & Induction of MS relapses & $\begin{array}{l}\text { Strongly supports the role of Th1 cells as } \\
\text { major pathogenic cells in MS }\end{array}$ \\
\hline $\begin{array}{l}\text { TNF inhibition by } \\
\text { sTNFR-IgG p55 }\end{array}$ & $\begin{array}{l}\text { Worsened } \\
\text { disease }\end{array}$ & $\begin{array}{l}\text { Blocks interaction of TNF with TNF-receptors; } \\
\text { ameliorated EAE }\end{array}$ & $\begin{array}{l}\text { Induction/prolongation of } \mathrm{MS} \\
\text { relapses }\end{array}$ & $\begin{array}{l}\text { Demonstrated that inhibition of cyto- } \\
\text { kines with pleiotropic effects is } \\
\text { complicated; the fusion protein inhibited } \\
\text { both proinflammatory (mediated by } \\
\text { TNFR1) and remyelinating/repair-fostering } \\
\text { (mediated by TNFR2) effects of TNF }\end{array}$ \\
\hline TGF- $\beta$ & None & $\begin{array}{l}\text { Was given with the idea to mediate } \\
\text { immunoregulatory effects; ameliorated EAE }\end{array}$ & $\begin{array}{l}\text { Severe compromise of kidney } \\
\text { function (drop in glomerular } \\
\text { filtrating rate) during phase I } \\
\text { testing in MS }\end{array}$ & $\begin{array}{l}\text { Has too many other effects than immune } \\
\text { regulation; not suited as } \\
\text { immunomodulatory treatment }\end{array}$ \\
\hline $\begin{array}{l}\text { Altered peptide ligand } \\
\text { (APL) }\end{array}$ & $\begin{array}{l}\text { Worsened } \\
\text { disease }\end{array}$ & $\begin{array}{c}\text { APLs showed ameliorating effects in EAE } \\
\text { models; given in MS with the idea to } \\
\text { antagonize autoreactive T cells or to induce a } \\
\text { Th1-Th2 shift }\end{array}$ & $\begin{array}{l}\text { Induction of relapses; local } \\
\text { reactions }\end{array}$ & $\begin{array}{l}\text { Relapses were caused by APL-specific Th1 } \\
\text { cells cross-reacting with native MBP } \\
\text { peptide strongly supporting a role of } \\
\text { myelin-specific Th1 cells in MS }\end{array}$ \\
\hline $\begin{array}{c}\text { Anti-IL-12/-23 } \\
\text { p40(ustekinumab) }\end{array}$ & None & $\begin{array}{l}\text { Shows therapeutic afficacy in psoriasis; } \\
\text { ameliorated EAE; was used in MS with the } \\
\text { idea to inhibit pathogenic Th17 cells }\end{array}$ & Does not apply & $\begin{array}{l}\text { Lack of efficacy questions a role of Th17 } \\
\text { cells in MS, since these cells play a major } \\
\text { role in psoriasis }\end{array}$ \\
\hline $\begin{array}{l}\text { Anti-BAFF/APRIL } \\
\text { (atacicept; a fusion } \\
\text { protein of TACl, the } \\
\text { transmembrane } \\
\text { receptor that binds } \\
\text { BAFF and APRIL with } \\
\text { the Fc portion of IgG) }\end{array}$ & $\begin{array}{l}\text { Worsened } \\
\text { disease }\end{array}$ & $\begin{array}{c}\text { Was used to block B cells assuming that B cell } \\
\text { activation/proliferation plays an important } \\
\text { role in MS }\end{array}$ & $\begin{array}{l}\text { Increased the relapse rate in } \\
\text { RRMS }\end{array}$ & $\begin{array}{l}\text { Since this approach appears effective in } \\
\text { SLE, where antibodies play a key } \\
\text { pathogenic role, the B cell-associated } \\
\text { pathomechanisms in SLE and MS must be } \\
\text { different. So far, the failure of Atacicept in } \\
\text { MS is not understood. }\end{array}$ \\
\hline
\end{tabular}


* filed for approval in MS; already approved in some countries 
